om de arbeidsovereenkomst met een jaar te verlengen. Het aanbod kon tot 31 maart 2020 worden aanvaard en na aanvaarding gold voor Sow een nader in de arbeidsovereenkomst genoemde beloning met als basis een bruto maandsalaris van EUR 4.000. Bij brief van 26 april 2019 heeft RKC wegens goede prestaties van Sow vroegtijdig gebruikgemaakt van het overeengekomen optiebeding en Sow meegedeeld dat zijn arbeidsovereenkomst was verlengd tot en met 30 juni 2021. Begin juli 2020 heeft de zaakwaarnemer van Sow RKC op de hoogte gebracht van interesse in Sow, zich namens Sow op het standpunt gesteld dat het optiebeding niet rechtsgeldig was overeengekomen en RKC verzocht mee te werken aan een transfer. RKC heeft niet gereageerd op het verzoek van Sow.

Partijen hebben de arbitragecommissie gevraagd om een oordeel over de rechtsgeldigheid van het optiebeding. Onder verwijzing naar haar eigen uitspraken, de uitspraken van de FIFA Dispute Resolution Chamber en het Court of Arbitration for Sport, heeft de arbitragecommissie vooropgesteld dat uit voornoemde uitspraken niet volgt dat optiebedingen naar hun aard niet steeds geldig worden geacht. De arbitragecommissie heeft overwogen dat uit de uitspraken ook niet volgt dat ieder optiebeding steeds geldig kan worden geacht en dat het aan de commissie is om op grond van alle omstandigheden van het geval de rechtsgeldigheid van een optiebeding te beoordelen. Bij die beoordeling spelen de volgende vijf criteria een belangrijke rol: i) de potentiële maximumduur van het dienstverband mag niet excessief lang zijn; ii) de optielichting dient geruime tijd voor de expiratiedatum van de initiële arbeidsovereenkomst aan de speler te zijn meegedeeld; iii) het salaris dat de speler zou gaan verdienen in de optieperiode dient reeds in het eerste contract te zijn benoemd; iv) de speler moet voldoende voordeel hebben van het lichten van de optie; v) de optie dient duidelijk aangegeven en benadrukt te zijn in de arbeidsovereenkomst en de speler dient daarvan volledig op de hoogte te zijn op het moment dat hij de arbeidsovereenkomst ondertekent. Daarnaast acht de commissie het van belang of de speler tijdens de contractonderhandelingen al dan niet voldoende is vertegenwoordigd.

De door Sow tegen het optiebeding aangevoerde bezwaren zijn verworpen door de commissie. De commissie heeft daarbij onder meer overwogen dat het in de voetballerij niet ongebruikelijk is dat spelers, indien zij presteren, in de belangstelling komen te staan van andere clubs. Dergelijke belangstelling maakt het (al dan niet) gelichte optiebeding volgens de commissie op zichzelf niet meer of minder rechtsgeldig. Met betrekking tot het vroegtijdig inroepen van het beding heeft de commissie overwogen dat dit juist in het voordeel van Sow te achten is vanwege het verlengde perspectief dat hem daarmee werd geboden.

Een door Sow gevorderde ontbinding van de arbeidsovereenkomst is door de commissie afgewezen. De arbeidsovereenkomst kan op verzoek van een werknemer worden ontbonden wegens omstandigheden die van dien aard zijn dat de arbeidsovereenkomst billijk- heidshalve dadelijk of na korte tijd behoort te eindigen (art. 7:671c BW). Volgens de commissie bestaat daarvoor in professionele verhoudingen alleen in bijzondere omstandigheden voldoende rechtvaardiging en van die bijzondere omstandigheden, waaronder bijvoorbeeld een voldoende financiële verbetering, is in deze casus niet gebleken. Hoewel Sow wel heeft gesteld dat hij zich financieel extreem kon verbeteren, is Sow - wegens een betwisting daarvan door RKC - er niet in geslaagd voldoende bewijs te leveren, zodat de commissie niet heeft kunnen beoordelen of Sow zich daadwerkelijk financieel voldoende heeft kunnen verbeteren.

NB. De arbitragecommissie heeft de afgelopen jaren in meerdere zaken het eenzijdige optiebeding toelaatbaar geacht, ${ }^{2}$ zo ook in deze procedure.

\section{VSZ 2021/4}

Rb. Noord-Holland 29 oktober 2020,

ECLI:NL:RBNHO:2020:8553 (Profvoetballer/Albert HeijinEMM\&ECV)

Toestemming tot gebruik portret profvoetballer voor promotie van voetbalplaatjesactie ligt besloten in bij cao gegeven toestemming tot exploitatie van het portret.

Op de arbeidsovereenkomst van eiser, profvoetballer bij ADO Den Haag, is de CAO voor contractspelers betaald voetbal Nederland 2017-2021 (cao) van toepassing. De cao regelt dat de 'Stichting CAO voor contractspelers' (Stichting) wordt opgericht voor de exploitatie van collectieve commerciële rechten van de bij de cao aangesloten voetbalclubs en voetballers (art. 22). De Stichting heeft aan Eredivisie C.V. (ECV), en later aan Eredivisie Media \& Marketing C.V. (EMM), een licentie verleend om de collectieve commerciële rechten te (doen) exploiteren. ECV en EMM hebben vervolgens (indirect) aan Albert Heijn B.V. (Albert Heijn) toestemming gegeven om de collectieve commerciële rechten te exploiteren in een landelijke voetbalplaatjesactie. Eiser is van oordeel dat Albert Heijn (ook), door het portret van eiser individueel af te beelden op posters in de winkels en via social media-kanalen, het individuele portret van eiser gebruikt ter promotie van de voetbalplaatjesactie. Eiser zou Albert Heijn hiervoor geen toestemming hebben gegeven en daarmee zou Albert Heijn inbreuk op zijn portretrecht maken. Eiser vordert de rechtbank om Albert Heijn te verbieden inbreuk te maken op zijn portretrecht en om te verklaren dat hij aanspraak maakt op schade vanwege portretrechtinbreuk. Subsidiair verzoekt hij toewijzing van een redelijke vergoeding, gelijk aan de misgelopen inkomsten die hij zou hebben verworven als hij wel om toestemming

2. College van Arbiters KNVB 4 juni 2004, JAR 2004/239 (Ajax/Hatem Trabelsi); College van Arbiters KNVB 29 augustus 2014, nr. 1408 (Letschert/Roda JC). 
voor exploitatie van zijn portret door Albert Heijn was gevraagd. ECV en EMM hebben zich aan de zijde van Albert Heijn gevoegd in de procedure.

De rechtbank stelt vast dat niet ter discussie staat dat eiser toestemming heeft gegeven aan de Stichting voor het gebruik van de aan hem individueel toekomende portretrechten ten behoeve van de exploitatie van collectieve commerciële rechten. De rechtbank onderzoekt vervolgens of deze toestemming zich mede uitstrekt tot de promoties van het portret van eiser ten behoeve van de voetbalplaatjesactie van Albert Heijn. Hierbij neemt de rechtbank onder meer in ogenschouw dat art. 22 cao geen limitatieve opsomming betreft van het exploiteren van collectieve commerciële rechten en dat de gedachte achter de bepaling kennelijk is dat het om gezamenlijke in het economisch verkeer verzilverbare aanspraken van de voetbalclubs en -spelers gaat, waarbij het collectief centraal staat en niet het individu. Volgens de rechtbank staat het collectief centraal nu juist de voetbalplaatjesactie gaat om het bij elkaar sparen van alle collectieve plaatjes (alle spelers en andere plaatjes, zoals speelsters van het Nederlands damesteam, clublogo's, trainers, en teamfoto's).

De rechtbank is voorts van oordeel dat Albert Heijn haar voetbalplaatjesactie moet kunnen promoten op de wijze zoals zij dat heeft gedaan. Weliswaar zijn er posters en berichten op social media-kanalen geopenbaard met uitsluitend het portret van eiser dan wel met uitsluitend portretten van een aantal van de andere voetbalspelers, doch deze posters en berichten maken gezien hun context onmiskenbaar onderdeel uit van een groter geheel, namelijk de promotie van de voetbalplaatjesactie als geheel. Evenredig en gelijkmatig gebruik van de (individuele) portretten van alle voetbalspelers is voor de promotie van de voetbalplaatjesactie geen vereiste volgens de rechtbank. Het gaat daarnaast bij de promotie van de voetbalplaatjesactie om gebruik van het portret van eiser dat redelijkerwijs was te voorzien omdat dit een gebruikelijke wijze van promotie is bij een dergelijke spaaractie. De rechtbank komt tot de conclusie dat de toestemming van eiser ten behoeve van de exploitatie van de collectieve commerciële rechten, waaronder via de voetbalplaatjesactie, mede wordt geacht te omvatten toestemming voor de promotie van de voetbalplaatjesactie zoals Albert Heijn dat heeft gedaan. De vorderingen van eiser worden afgewezen.

NB. Het is niet ongebruikelijk in Nederland dat profsporters, clubs of bonden toestemming geven voor het (collectief) exploiteren van hun portret tezamen met dat van andere sporters. In het profvoetbal is deze toestemming in de geldende cao verankerd. De reikwijdte van collectieve exploitatie kan daarbij ter discussie komen, zoals in de onderhavige zaak, waarin werd geoordeeld dat de toestemming voor collectieve exploitatie van profvoetballers mede wordt geacht te omvatten redelijkerwijs voorzienbare promotieactiviteiten met gebruik van individuele portretten.
VSZ 2021/5

College van Arbiters KNVB 30 oktober 2020, nr. 1529 (Maletic/PSV)

Hoewel jeugdtrainer Maletic onterecht door PSV op staande voet is ontslagen, gaf zijn handelen aanleiding tot een matiging van de ontslagvergoedingen.

Met ingang van 1 juli 2019 trad Stefan Maletic (Maletic) voor bepaalde tijd voor de duur van twee jaar in dienst bij PSV N.V. (PSV) in de functie van jeugdtrainer tegen een bruto jaarsalaris van EUR 30.500 ex emolumenten. In de arbeidsovereenkomst ontbrak een tussentijds opzegbeding.

Op initiatief van Maletic heeft er in april 2020 tussen hem en een contractspeler van PSV WhatsApp-contact plaatsgehad over een mogelijke transfer van de speler naar een voetbalclub in de Emiraten. Op 1 mei 2020 heeft hierover een gesprek plaatsgevonden tussen PSV en Maletic, waarin PSV Maletic te kennen gaf het niet te accepteren dat hij heeft getracht een speler van PSV te bewegen tot een transfer. Ondanks een gedeeltelijke ontkenning en verontschuldigingen van Maletic, liet PSV hem weten geen vertrouwen meer te hebben in een vruchtbare voortzetting van de arbeidsovereenkomst. PSV zond Maletic op 1 mei 2020 in concept een vaststellingsovereenkomst ter beëindiging van de arbeidsovereenkomst met het verzoek deze overeenkomst nog dezelfde dag voor 23.00 uur te tekenen, met daarbij de opmerking dat wanneer hij niet akkoord ging, PSV nadere juridische stappen zou nemen. Maletic heeft de overeenkomst niet getekend, waarna PSV hem per brief, die door Maletic op 3 mei 2020 is ontvangen, op staande voet heeft ontslagen wegens het voor - kort gezegd eigen zakelijk gewin trachten een werknemer van PSV te bewegen zijn arbeidsovereenkomst met PSV te beëindigen. In de brief is voorts opgemerkt dat PSV hem in het gesprek op 1 mei 2020 te kennen heeft gegeven dat zijn arbeidsovereenkomst werd opgezegd wegens een dringende reden ex art. 7:677 BW. Maletic heeft de opzegging per 1 mei 2020 betwist, zich verzet tegen het ontslag en zich beschikbaar gesteld om zijn werk te hervatten. In de procedure heeft Maletic zich neergelegd bij de beëindiging per 1 , respectievelijk 3 mei 2020 en ontslagvergoedingen gevorderd.

Volgens de arbitragecommissie is niet komen vast te staan dat Maletic op 1 mei 2020 door PSV op staande voet is ontslagen. Voorts is de arbitragecommissie tot het oordeel gekomen dat de brief van 3 mei 2020 rechtsgevolg mist, omdat daarin is verwezen naar de opzegging op 1 mei 2020 die naar het oordeel van de commissie niet is komen vast te staan. Overigens heeft de arbitragecommissie geoordeeld dat een ontslag op staande voet niet met terugwerkende kracht kan worden gegeven, in die zin dat PSV met de brief van 3 mei 2020 de arbeidsovereenkomst dus niet per 1 mei 2020 met onmiddellijke ingang heeft kunnen doen beëindigen. Op 